\title{
AMYGDALOIDAL SPILITIC DIKES IN HOUTSKÄR, SW FINLAND
}

\author{
Nils Edelman
}

\begin{abstract}
Edelman, Nirs 1972: Amygdaloidal spilitic dikes in Houtskär, SW Finland. Bull. Geol. Soc. Finland 44, 103-106.

Dikes with a spilitic composition and amygdales filled with quartz, calcite and opaque minerals cut veined gneisses on the island of Bockholm, in the commune of Houtskär, SW Finland. The dikes strike almost at right angles to the general strike of the diabase dikes in the archipelago. The quartz and feldspar of the country rock have locally corroded the contacts of the dikes and also filled two cross joints in a thin spilitic epiphysis. These dikes represent a new type and probably a new generation of dikes in the archipelago of SW Finland.
\end{abstract}

Nils Edelman, Abo Akademi, 20500 Abo 50, Finland.

\section{Description}

In connection with geological mapping for the Geological Survey in the archipelago of SW Finland some dark dikes were found on the NW shore of the island of Bockholm (21⒒2' E and $59^{\circ} 19.0^{\prime} \mathrm{N}$ ) in the NW part of the commune of Houtskär. There are two broad dikes and some thin apophysic or epiphysic veins. The northern dike is 75 centimetres broad and the southern one 30 centimetres tapering eastwards to 5 centimetres before it becomes hidden by drift. The satellitic veins are short and about one centimetre broad.

The northern dike has $10-15$ centimetre broad finegrained chilled contact zones (Figs. 1 and 2). The inner part of the dike is somewhat coarser, amygdaloidal and contains some big reddish feldspar phenocrysts with megascopically good crystal shape. The southern dike is partly hidden by lichens and is therefore more difficult to study in detail.

The contacts are as a rule sharp and straight, but locally they are fringed as a result of jointing in the country rock (Fig. 1). In some places, the light minerals of the veined gneiss make lobate indentations in the contact of the spilitic dike (Fig. 2). One of the satellitic veins is broken and cut at two points by material from the country rock (Fig. 1). These observations point to recrystallization or mobilization of the gneiss after the hardening of the spilite. Similar palingenic or rheomorphic country rock dikes have been described from diabases in other parts of Finland (Kahma 1951, Laitakari 1969). A peculiar structure in the contact between a diabase dike and a gneiss in Stortervo, in the commune of Pargas, has been explained in a similar way (Edelman 1949).

The spilite is porphyritic. The inner parts of 


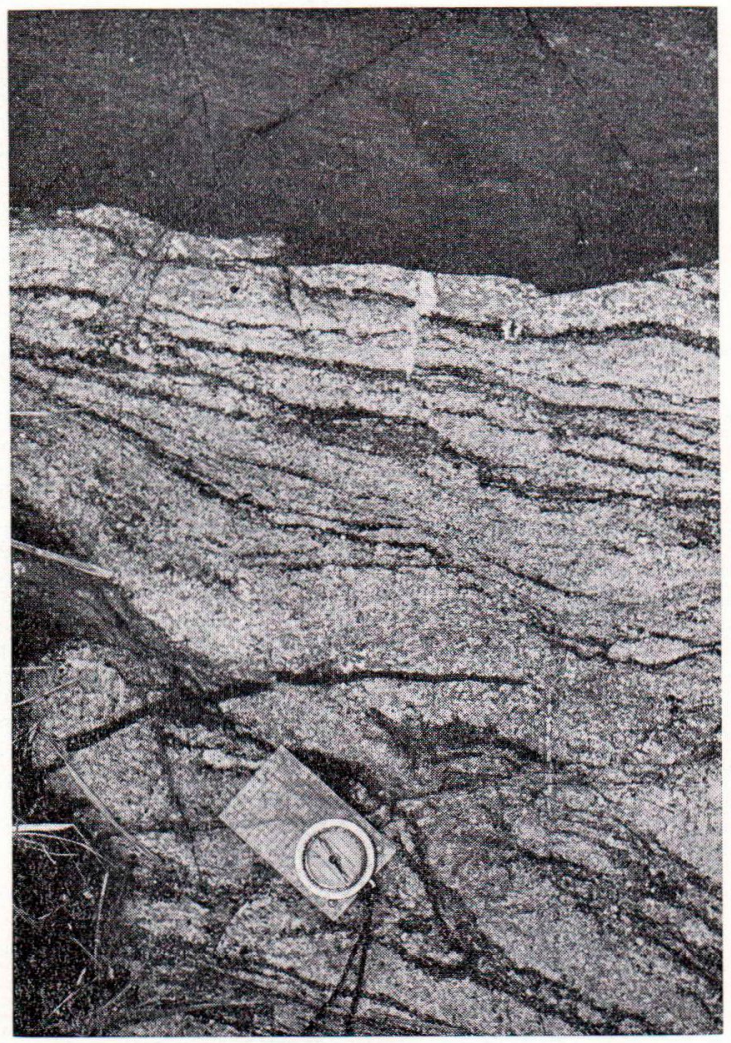

FIG. 1. A spilitic dike with a sharp chilled contact. Just above the compass, a thin satellitic vein which is cut by the the mobilized gneiss at two points.

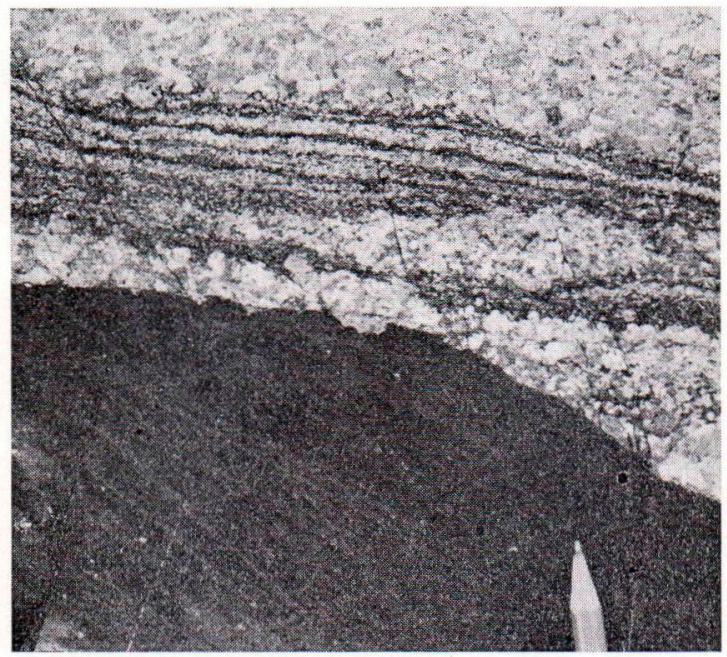

FIG. 2. A contact of a spilitic dike with signs of replacement by the recrystallized gneiss.

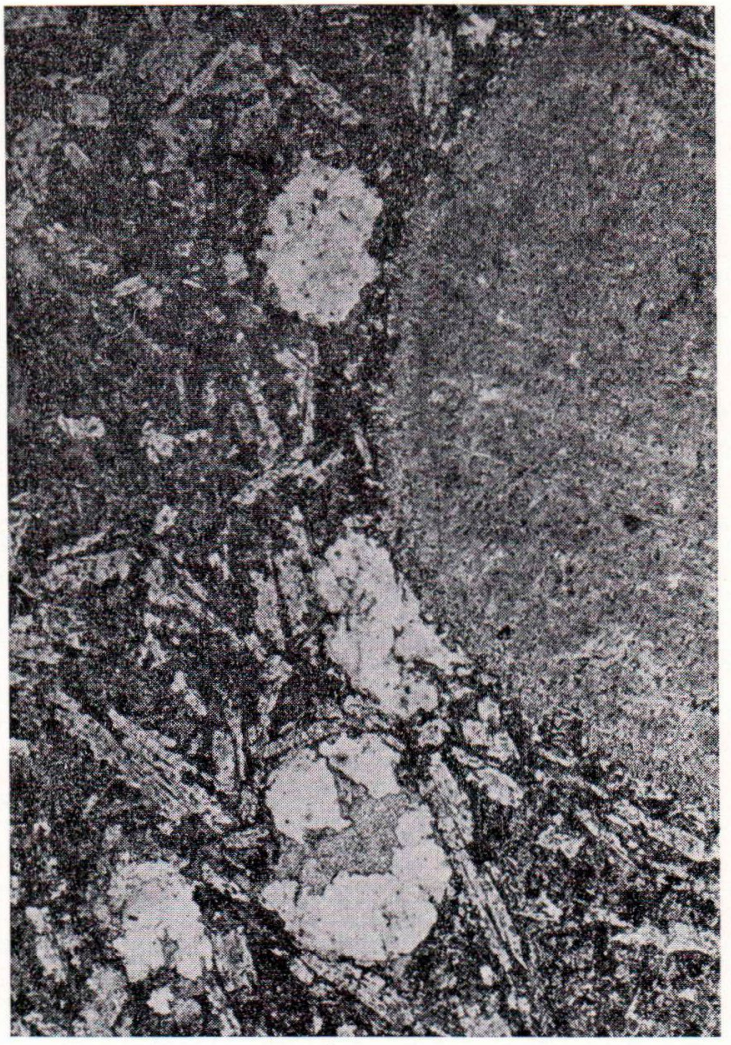

FIG. 3. Photomicrograph of the central part of a spilitic dike with a large albite phenocryst and amygdales filled with quartz and calcite. One nicol, $35 \mathrm{x}$.

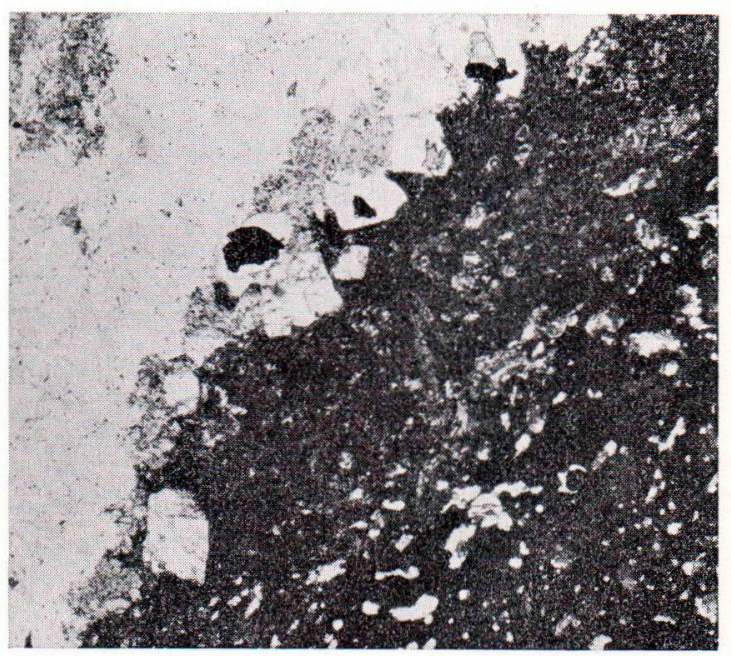

FIG. 4. Photomicrograph of the chilled contact of a spilitite dike with signs of flow strucuret parallel to the contact. The contact is uneven as a result of recrystallization of the gneiss. One nicol, $35 \mathrm{x}$. 
the dikes have an almost ophitic texture with rounded amygdales (Fig. 3), whereas the finegrained chilled contacts have a flow structure with parallel oriented feldspars, and elongated amygdales (Fig. 4). The main minerals of the spilite are albite, chlorite, biotite and magnetite. Albite forms phenocrysts with good crystal shapes. As a rule they contain sericite and pigment. Rarely, grains of epidote are present. The phenocrysts are commonly less than one millimetre long but a few of them are 20-30 millimetres. These large grains represent an older generation. Although they megascopically show crystal shapes, their corners are rounded when seen under the microscope (Fig. 3). Some of them consist of plumose aggregates of albite and contain angular quartz grains without any crystal shape.

The principal dark minerals are chlorite and biotite. They fill the interstice between the albite grains. The biotite seems to be concentrated on the vicinity of the contacts. The chlorite is pale green and weakly pleochroic. Some chlorite grains may be up to one millimetre long but they are usually much smaller. Intergrowth between chlorite and biotite is common. In some cases the chlorite contains elongated ore grains in regular patterns, occasionally with two directions almost at right angles to one another giving the impression of a relict cleavage. This indicates that the chlorite is obviously an alteration product of primary pyroxene, or possibly of amphibole. Magnetite also occurs as somewhat larger equidimensional grains and forms a minor constituent of the rock, which is therefore moderately magnetic. Other alteration products are calcite, sericite and rarely epidote.

The amygdales are commonly about one millimetre in diameter, but a few of them are considerably larger. In the central part of the dikes they are well rounded (Fig. 3) but close to the contacts they are small and strongly elongated parallel to the contacts. They are filled with quartz and calcite, more rarely with opaque minerals. Quartz has crystallized first and calcite fills the interstice.
Some observations point to contact metamorphism in the country rock. A grain of fluorite is found in one slide in the gneiss close to the contact. In this region fluorite is only found in the postorogenic granites and therefore this fluorite grain points to supply from the dike. In another slide, a grain with graphic intergrowth of plagioclase and quartz lies close to the contact with the dike. Because this is the only grain with such a texture it would also seen to be a result of contact metamorphism. Kahma (1951) and Laitakari (1969) have described similar textures from palingenic or rheomorphic dikes in diabases.

The contacts between the dikes and the gneiss are in general sharp, also under the microscope, but in some cases they are more diffuse with minerals from both rocks intermingled (Fig. 4). The minerals of the gneiss also form many lobes in the contacts of the dikes (Fig. 2).

\section{Discussion}

The described dikes have many features differing from the common diabase dikes of the archipelago. They strike almost at right angles to the latter which in general strike N-NE (Sederholm 1934, Hausen 1964). This indicates that the stress in the crust had entirely different directions during the intrusions of these two types of dikes. The mineral composition of the present dikes is spilitic in contrast to the basaltic composition of the diabases. The abundant amygdales point to a magma rich in volatiles and to an intrusion on such a high level that the gas pressure exceeded the external pressure of the superposed crust. Amygdales are rare in the diabases.

The pseudomorphs after pyroxene or perhaps amphibole, which now consist of chlorite and magnetite, as well as the plumose texture of the albite aggregates in the large phenocrysts, indicate strong recrystallization during the latest stage of or after the consolidation of the dikes. Hence the mineral composition seems to be largely secondary and a result of autometamorphic processes. The high content of volatiles 
is the obvious cause of this spilitization. In some places the volatiles may also have mobilized the felsic minerals of the gneiss to such an extent that they recrystallized, resorbed the contacts and filled the cross joints in the satellitic veins. As these spilitic dikes cut migmatic rocks, the high content of volatiles and sodium cannot have been extracted from unconsolidated marine sediments as was formerly proposed to explain the composition of the spilites.

\section{REFERENCES}

Edelman, Nils (1949): Structural History of the Eastern Part of the Gullkrona Basin, SW-Finland. Bull. Comm. géol. Finlande, 148, 48 p.

Hausen, Hans (1964): Geologisk beskrivning över landskapet Åland. Skrifter utgivna Ålands kulturstiftelse, IV, $196 \mathrm{p}$.

Kahma, Aarno (1951): On Contact Phenomena of the Satakunta Diabase. Bull. Comm. géol. Finlande, 152, 84 p.
LAItAkARI, IlKkA (1969): On the set of olivine diabase dikes in Häme, Finland. Bull. Comm. géol. Finlande, 241, 65 p.

Sederholm, J. J. (1934): On Migmatites and Associated Pre-Cambrian Rocks of Southwestern Finland. Part III. The Åland Islands. Bull. Comm. géol. Finlande, 107, 68 p.

Manuscript received, October 28, 1971. 